\title{
COMBINED THERAPY FOR PATIENTS AFTER ISCHEMIC STROKE FROM THE POINT OF VIEW OF COMPREHENSIVE REHABILITATION
}

\author{
MICHAL VOSTRÝ \\ Jan Evangelista Purkyně University in Ústí nad Labem \\ Faculty of Health Studies and Faculty of Education \\ Velká Hradební 13, 400 96, Ústí nad Labem, Czech Republic \\ E-mail address: Michal.Vostry@ujep.cz \\ ORCID: https://orcid.org/0000-0003-4749-3095 \\ LADISLAV ZILCHER \\ Jan Evangelista Purkyně University in Ústí nad Labem \\ Faculty of Education \\ České mládeže 8, 40001 Ústí nad Labem, Czech Republic \\ E-mail address: Ladislav.Zilcher@ujep.cz \\ ORCID: https://orcid.org/0000-0002-9551-1035
}

\begin{abstract}
Aim. The main objective of the research was to find out the efficacy of the combined therapy suitable for patients after ischemic stroke (promoting social adaptability). The therapy itself is then focused on robotic, psychomotor and cognitive therapy.

Methods. 58 probands diagnosed with a stroke participated on the research (ischemic type I60-I69; ICD-10: International Classification of Diseases and Related Health Problems), out of whom 49 were male patients ages between 50-55 and women between the age of 52-57. The data collection was finished in 2017-2018. Indicators were evaluated and tested firstly after the initiation of the combined therapy, then after 15 weeks of intensive therapy, which took place 4 times a week for 50 minutes for each patient participating in the research.

Results. A statistically significant difference was recorded among all observed indicator areas (somatic, psychological, social and even cognitive), in which patients scored significantly better results during the final testing than during the initial testing.

Conclusion. The results of the research point to the fact that the combined therapy of robotic, psychomotor and cognitive can have positive effect, and is suitable as a treatment for patients after ischemic stroke, regarding their productive age. Positive results have been therefore overt among all tested areas.

Key words: stroke, cognitive therapy, combined therapy, psychomotor therapy, robotic therapy, social adaptability, occupational therapy, special education, helping professions
\end{abstract}




\section{INTRODUCTION}

Despite the current development in treatment, care and prevention ischemic stroke is an overtly pervasive global and world-wide discussed clinical phenomenon, as well as a socioeconomic issue. In the Czech Republic alone, in 2016, more than 19000 patients with this diagnosis were hospitalized and treated in specialized cerebrovascular medical centre's (Tomek, Bar, Herzig, Mikulík, Neumann, Šaňák, \& Václavík, 2017). This is the most frequent acute disease/illness among neurology patients. A third of diagnosed patients succumb to their state every year and more than a half of all cases who survive have severe limitations of cognitive and motor functions. This makes them permanently dependent on the care of others (Adamičová, 2003). A very important key measure for patients after ischemic stroke is mainly secondary type of prevention, which needs to be taken into consideration as a complex approach including not only pharmacological therapy, but also nonpharmacological solutions (Šaňák, 2018). These among other measures have the goal to minimize the danger of relapse, or further deterioration of the current state of the patient. When it comes to resocialization of patients after ischemic stroke, substitution or resuscitation of damaged functions plays a key role in the treatment process. The greatest challenges and deficiencies can be then detected while performing daily tasks, such as hygiene, eating habits, mobility or verticalization, etc. Speech impairments and disorders such as aphasia or dysarthria are diagnosed in over $60 \%$ of the population after suffering from an ischemic stroke (Konečný, Vysoký, Elfmark, \& Urbánek, 2017). One of the most serious deficiencies, apart from locomotion issues, are also cognitive issues (Šaňák, 2018). These can be detected in over $92 \%$ of all diagnosed cases. In the acute state after ischemic stroke, cognitive function may also fluctuate, thus the minimum duration for any cognitive function testing is set to a 3-month threshold after a stroke episode (Škoulodík et al., 2017). The modern approach in the rehabilitation process suitable for patients with ischemic stroke mainly relies on robotic therapy. Robotic walking motion rehabilitation represents an advanced rehabilitation technology which has become the centre of attention of the academic and professional society. This approach originates from a modification of treadmill rehabilitation processes to improve walking motion in tow or relaxed movement (Diets, 2009).

\section{METHODOLOGY}

The main objective of the research was to find out how effective the combined therapy was for patients diagnosed with ischemic stroke (both embolic and thrombotic type) according to the classification of disorders, listed as I60-I69; MKN-10. The Therapy focused mainly on robotic, psychomotor and cognitive therapy and skill development. Somatic, psychological, social and cognitive indicators were tested and observed among 58 selected patients, 
out of which 49 were male, aged 50-55, and women, aged 52-57, who have not been diagnosed with any speech impairment. The overall data was collected in the years 2017-2018. The indicators were evaluated and assessed after the combined therapy was initiated, then again after 15 weeks of intensive therapy. The therapy itself then took place 4 times a week, mainly by individual appointments with patients, each about 50 minutes per patient, based on individual needs and possibilities of each patient. The main methodology used for assessment was the international classification of illnesses and disorders (ICD-10), Functional Independence Measure (FIM). Based on the previously mentioned criteria, the following indicators were selected for analysis:

- Cognitive and psychological indicators: state, mood changes, willpower, focus, orientation and memory;

- Somatic indicators: endurance, movement coordination, stability range of movement;

- Daily routine task indicators: dressing, hygiene, eating; model activities;

- Social indicators: adaptability, collaboration;

- $\quad$ Research sample: 58 patients (100\%), out of whom 49 were men (aged 50-55; $84.5 \%$ of total) and 9 women (ages $52-57 ; 15.5 \%$ of total);

- Therapy: robotic therapy using the Amadeo ${ }^{\circledR}$ and BalanceTutor ${ }^{\mathrm{tm}}$; cognitive rehabilitation; psychomotor therapy; special education; occupational therapy; physiotherapy; comprehensive rehabilitation;

- Diagnosis: ischemic stroke (iCMP; Czech), (I60-I69; ICD-10);

- Assessment scales: (modified ICF; International Classification of Functioning, Disability and Health, FIM); 95.0\% Tukey HSD (honestly significant difference) test $a=0,05$;

The assessment has been done according to the previously mentioned methodology. In our case, this can be considered as a longitudinal and qualitative form of research.

\section{RESULTS}

The given questionnaire research resulted in the following findings: in case of somatic, psychological, social and cognitive indicators, we have found significant differences in all groups of indicators $(p<0,05$; also among other tested indicators), meaning the tested group with the ischemic stroke diagnosis has shown significant improvement over the initial testing. The presented results point to the fact that improvement has been overt among all tested indicators. In the case of daily tasks, mobility and social skills, the tested patient group improved mainly in areas of communication skills, verticalization, hygiene and mobility. 


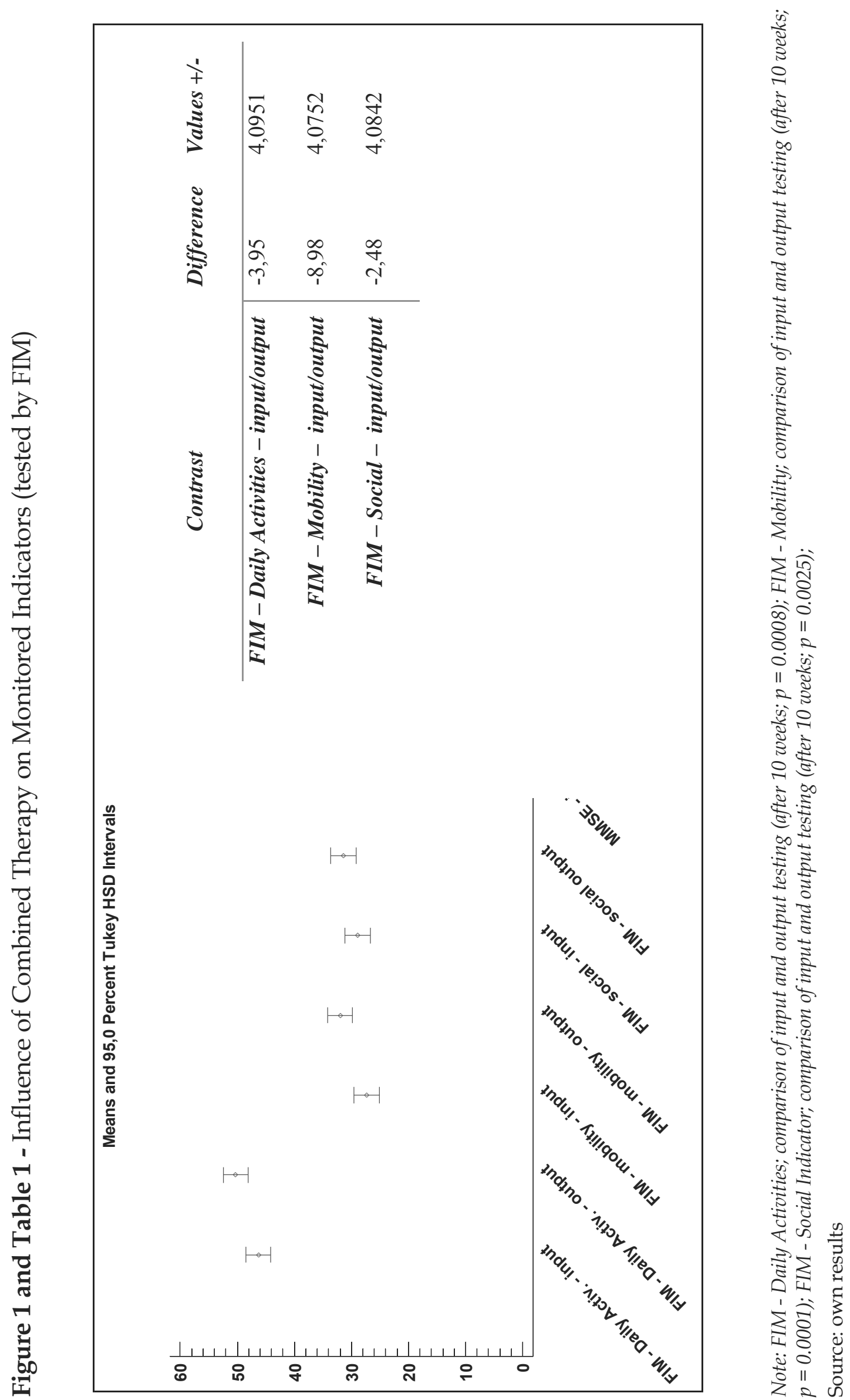




\section{DISCUSSION}

Based on the presented results, advisory measures were created in compliance with the evaluated results. Combination of somatic, psychological and cognitive deficiencies create an assumption that we have to initiate with somatic or psychological therapy, thus cognitive deficiencies are not prioritized and can be often neglected.

The presented results point to a conclusion that by development and treatment of all of the mentioned areas patients with cognitive disorders can positively improve their state, not just focus on one rehabilitation area. If our goal is to have patients to be socially adaptable, it is not possible to only build intervention on motor skill stimulation, but also cognitive training. The focal point of the intervention was mainly to support active movement in collaboration with elements of cognitive rehabilitation. Movement was stimulated via psychomotor therapy procedures, which are always undergone by active participation and movement, which also requires a certain amount of willpower to perform. This is a support method which to pharmacotherapy and surgery, can have beneficial effects (Flemr, 2014; Valenta, Michalík, \& Lečbych 2019). Robot therapy that was chosen for this particular study has become more popular over the recent years. Studies verify the positive effect on various research samples, and also predict that due to such intervention processes, testing and assessment methods should improve in the future. However, some studies view these outcomes not in such high esteem and are more sceptical towards the use of such intervention. In such studies the reasoning is that robot therapy may improve patient's motor skills, however the direct causation of the improvement has not been yet fully verified and further testing is required (Amman-Reiffer, Bastiaenen, Meyer-Heim, \& van Hedel, 2017).

\section{CONCLUSION}

The global target of society is currently to overcome the issues of aging population problems, which will require a gradual adaptation to a new demography. Objectives of such adaptation lay mainly in social exclusion and discrimination prevention of this age group with a particular disability. All measures of prevention then engage in active life style during lifetime and old age (Hátlová, Fleischmann, \& Chytrý, 2017). The presented study results, focused on patients with cognitive issues, show that combined efforts in psychomotor and robot therapy can have a positive effect on the observed area (cognitive functions, independence, social adaptability and somatic changes). Among all tested groups of patients there proved to be a significant point of improvement from the initial testing. It has to be also mentioned, however, that there are also limitations of the study results. The main issue, of course, is that the verification of the therapy efficiency is not a clear process. We may observe other countless variables, which may also influence the outcome of the test results. This considers mainly intrinsic and extrinsic conditions (Vostrý, Fischer, \& Žukov, 2019). 
This factor, which is also defined in the ICD -10, has not however been taken into account for the assessment, due to the fact, that the research sample contained only short-term hospitalized patients. Cognitive function deficiencies of various etiology are frequently neglected in practice, which is mainly overt among the population of patients after ischemic stroke, who show signs of cognitive and motor issues even after rehabilitation. The therapy is then devoted mainly to motor skill development more than to cognitive skills. This idleness and inactivity can, however, negatively influence the deficiency. Our main recommendation is, therefore, a regular and effective movement in compliance with cognitive training focused on specific areas of cognitive function (Vostrý, 2019).

\section{ACKNOWLEDGEMENT}

This research article was funded and supported by GC; grant competition (grant from Jan Evangelista Purkyně University in Ústí nad Labem).

\section{CONFLICT OF INTERESTS}

None declared.

\section{REFERENCES}

[1] Adamičová, H. (2003). Rehabilitace po cévní mozkové př́ihodě [Rehabilitation after Stroke]. In: Kolektiv autorů (Eds.), Neurologie (pp. 20-36). Praha: Triton.

[2] Ammann-Reiffer, C., Bastiaenen, C. H. G., Meyer-Heim, A. D., \& van Hedel, H. J. A. (2017). Effectiveness of robot-assisted gait training in children with cerebral palsy: a bicenter, pragmatic, randomized, cross-over trial (PeLoGAIT). BMC pediatrics, $17(1), 64$.

[3] Dietz, V. (2009). Body weight supported gait training: from laboratory to clinical setting. Brain Res Bull, 78 (1), 1-6.

[4] Flemr, L. (2014). Pohybové aktivity ve vědě a praxi [Physical Activities in Science and Practice]. Praha: Karolinum Press.

[5] Hátlová, B., Fleischmann, O., \& Chytrý, V. (2017). Osobnost a aktivní životní styl seniorů ve věku 65-75 let praxi [Personality and Active Lifestyle of Seniors Aged 65-75 Years of Practice]. Psychologie a jeji kontexty, 8 (1), 41-53.

[6] WHO. (2014). International Classification of Diseases (ICD-10). Geneva: WHO.

[7] World Health Organization. (2007). International Classification of Functioning, Disability, and Health: Children \& Youth Version: ICF-CY. World Health Organization.

[8] Konečný, P., Vysoký, R., Elfmark, M., \& Urbánek, K. (2017). Effects of Targeted Orofacial Rehabilitation in Patients after Stroke with Speech Disorders. Česká a Slovenská Neurologie a neurochirurgie, 80 (3), 316-322.

[9] Šaňák, D. (2018). The twilight of cryptogenic ischaemic stroke - cardio-embolism is the most frequent cause. Česká a Slovenská Neurologie a neurochirurgie, 81 (3), 290-297.

[10] Siverová, J., \& Bužgová, R. (2016). Reminiscence v péči o seniory s demencí. Česká a Slovenská Psychiatrie, 112 (2).

[11] Školoudík, D., Fadrná, T., Sedláková, M., Ressner, P., Bar, M., Zapletalová, O., \& Kaňovský, P. (2007). Změny kognitivních funkcí u pacientů s akutní cévní mozkovou příhodou testovaných pomocí Mini-Mental State Examination a Clock Drawing Test. Česk Slov Neurol, 103 (4), 382-387. 
[12] Tomek, A., Bar, M., Herzig, R., Mikulík, R., Neumann, J., Šaňák, D., \& Václavík, D. (2017). The impact of nationwide centrally organized stroke care system on recanalization rates: Czech Republic experience. European Stroke Journal, 2(1_suppl), 59-60.

[13] Valenta, M., Michalík, J., \& Lečbych M. (2010). Mentální postižení: v pedagogickém, psychologickém a sociálně-právním kontextu [Mental Disability: in a Pedagogical, Psychological and SocioLegal Context]. Praha: Grada.

[14] Vostrý, M. (2018). Selected opportunities for access to geriatric clients from the perspective of assisting professions. Journal of Education Culture and Society, 8 (1), 89-95.

[15] Vostrý, M., Fischer, S., \& Žukov, I. (2019). Podpora sociální adaptability osob s Alzheimerovou chorobou lehkého typu [Promoting the Social Adaptability of People with Light Type Alzheimer's Disease]. Česká a Slovenská psychiatrie, 115 (4); 174-178. 